\title{
Characterization of antioxidant properties of strawberry tree (Arbutus unedo L.) and trace elements determination
}

\author{
Gülbin ERDOĞAN $1 *$ (D), Tuğba UYSAL 2 (D) \\ 1 Department of Analytical Chemistry, Faculty of Pharmacy, Marmara University, 34854-Maltepe, Istanbul, Turkey. \\ 2 Institute of Health Sciences, Marmara University, 34854-Maltepe, Istanbul, Turkey. \\ * Corresponding Author. E-mail: gerdogan@marmara.edu.tr (G.E.).
}

Received: 14 August 2020 / Revised: 03 September 2020/ Accepted: 04 September 2020

\begin{abstract}
Strawberry tree (Arbutus unedo L.) is a species that generally grows in the Mediterranean region and coasts and has been consumed as food since ancient times. Its fruits are mostly used in alcoholic beverages and various jams and desserts. Its fruits and leaves contain different phenolic compounds, because of this it is used in traditional folk medicine. They have different biological properties like, anti-diabetic, anti-inflammatory, urinary antiseptic, antihypertension, astringent, anti-diarrheal due to their high quantity of tannins. In this study, we aimed that to determine the total antioxidant capacity of fruits and leaves and trace element contents of Arbutus unedo L. which were collected in Yalova (TURKEY). The antioxidant activities of samples were examined by ferric reducing/antioxidant power (FRAP) method, cupric reducing antioxidant capacity (CUPRAC) method and trolox equivalent antioxidant capacity (TEAC) assay with ABTS radical cation. In the samples of the amount of total phenolic and tannins contents were determined using the Folin-Ciocalteu reagent (FCR) method. In adddition to, we determined the concentrations of $\mathrm{Al}$, $\mathrm{Cd}, \mathrm{Cu}, \mathrm{Cr}, \mathrm{Fe}, \mathrm{Mn}, \mathrm{Pb}, \mathrm{Zn}$ in the samples by using ICP-MS. As a result, Arbutus unedo L. is a good source of antioxidants and minerals, it was stated that single antioxidant activity test would present limited information about the power of the antioxidant capacity and it was emphasized that use of combination of various methods should be used in assessing the antioxidant activities in vitro. It has been determined that the trace elements are within the determined limits.
\end{abstract}

KEYWORDS: Strawberry tree (Arbutus Unedo L.); CUPRAC; ABTS/TEAC; FRAP; Folin-Ciocalteu; trace elements.

\section{INTRODUCTION}

Phenolic compounds are molecules that have antioxidant activity and help protect cells against oxidative damage caused by free radicals. The protective effect of many herbal spices and herbs is due to the presence of antimicrobial components and antioxidants in their tissues. Polyphenolic compounds found in plants have multifunctional properties and play a role as reducing agent, hydrogen donor antioxidant and singlet oxygen suppressor. Antioxidants are molecules that limit the formation of radicals, complete their radical reactions and neutralize the formed radicals. When antioxidants are present in foods and the body in low concentrations, oxidation is significantly prevented or delayed in metabolism [1-3]. Therefore, there is an increasing interest in the antioxidant activity of radicals naturally occurring in food and biological systems. Antioxidant activity and antioxidant capacity terms have different meanings when used interchangeably. The activity includes the rate constant of the reaction between a specific antioxidant and oxidant. Capacity is a measure of the amount of a particular free radical swept by a sample. Antioxidant capacity measurements give the amount of a heterogeneous mixture of antioxidants, which determines the total scavenging ability of the sample. It does not measure the antioxidant capacity of each component. Antioxidants and antioxidant enzymes (e.g. creatine, arginine, taurine, zinc, citrulline, glutathione, vitamin E, vitamin A, vitamin C, selenium, tea polyphenols, glutathione peroxidase, glutathione reductase, catalase, and superoxide dismutase) apply synergistic activity in scavenging free radicals. In recent years, there has been evidence that malnutrition (for example, dietary lack of zinc, protein and selenium) or an excess of certain nutrients (for example, vitamin $C$ and iron) lead to oxidation of biomolecules and cell injury. A lot of literature supports the idea that dietary antioxidants are beneficial preservatives for metabolism and play an important role in the prevention of many diseases. Therefore, the interest in dietary sources containing phenolic compounds with antioxidant properties has increased day by day [4-6].

How to cite this article: Erdoğan G, Uysal T. Characterization of antioxidant properties of strawberry tree (Arbutus unedo L.) and trace elements determination. J Res Pharm. 2020; 24(5): 774-785. 
Strawberry tree (Arbutus unedo L.) is a genus which affiliations to the Vaccionioideae subfamily (or Arbutoideae, hanging on the author), and Ericaceae family. Arbutus unedo L., in Turkey, Mediterranean, Aegean, Marmara and in coastal areas of the Black Sea region grows wild and is also grown as culture (also known as Strawberry Tree) is a rich food source of phenolic compounds. Red fruits are a good source of antioxidants and contain high amounts of sugar. Arbutus unedo L. is an important fruit type for human health. Its fruits are rich in mineral elements and especially vitamin C (150-280 mg) [7-8]. Orak et al. evaluated some nutritional components and antioxidant activity properties of Arbutus unedo L. fruit by drying and freezing. They used DPPH radical scavenging activity and $\beta$-carotene bleaching method for the determination of antioxidant activities and it was observed that the nutritional values of freeze dried fruit analysis made better antioxidant activities [9].

The leaves carry phenolic substances such as tannins, arbutin, methylarbutin. It contains tannins $(45 \%)$ in bark and roots $[9,10]$. It has been proven to have effective activity due to the high polyphenolic content of Arbutus unedo L., which is determined to contain various phenolic compounds such as flavonols, ellagic acid and anthocyanins. Arbutus unedo L. fruits usually contain high amounts of flavonoids such as proanthocyanidins and anthocyanins such as delphinidine, cyanidine-3-galactoside. The fruits of Arbutus unedo L, an important source of nectar and pollen for bees, ripen within a year. Therefore, there are both flowers and ripe fruit at the same time. Although the appearance of the fruit is beautiful, it is rarely consumed as a fruit because its taste is not that good. Until now, they are mainly used for getting jellies marmalades, jams and alcoholic drinks. They can be used in making fruit yoghurt, fillings pies and pastries, confectionery such as grain products inside another the same applications [11,12]. Fruits strengthen the body and protect against germs. It improves kidney and bladder inflammation, sheds intestinal worms, is good for liver failure, melts tooth stones, helps to shed gallstones, strengthens nerves. If the liquid obtained from boiled fruits is drunk, it is good for measles, diuretic, cough and bronchitis, lowers high blood pressure, relieves vascular stiffness, good for rheumatism and joint inflammation, lowers fever, gives freshness and beauty to the skin. The leaves have anti-diabetic, anti-inflammatory, urinary antiseptic, anti-hypertension, astringent [13-16].

Plants, which have been used as treatment and food since ancient times, have been an important source in the production of herbal medicines in terms of pharmacology. Therefore, determining the components of medicinal plants is necessary for health. The element levels in the content of fruit vegetables should be within the limit levels determined by the World Health Organization (WHO). Because while the minerals and elements in its content should be at the required level in metabolism, being excessive also causes toxicity. Undesirable results occur as a result of excessive accumulation of these elements in the body at levels that may endanger the health of people. For this reason, the amount of trace elements in the plant that the plant takes from the soil, air and water changes depending on the environment and climatic conditions in which the plant grows. For this reason, it is absolutely necessary to carry out trace element and mineral analysis in plants to be used as food and in medicine [17].

Various methods have been developed to determine the antioxidant properties of substances until today. The methods for the determination of antioxidant capacity, in terms of chemical reactions, basically can be divided into two classes. These;

1) Those based on hydrogen atom transfer (HAT) reactions

2) Those based on single electron transfer (ET) reactions

Competitive reaction kinetics are tracked in HAT-based analysis methods and the quantitation is derived from kinetic curves. HAT-based methods consist of synthetic free radical generators, oxidizable probes and antioxidants. ET-based analysis methods are based on the measurement of the antioxidant capacity to reduce an oxidant substance that changes color when reduced $[18,19]$.

Our aim was to extract the fruits and leaves of the strawberry tree Arbutus unedo L. using different proportions of methanol and then to compare the total phenolic and tannin content of these extracts with different antioxidant methods. Trace element contents were also determined by analysis.

\section{RESULTS}

\subsection{The suitable solvent for Arbutus unedo $\mathrm{L}$.}

In determining the suitable solvent for extraction processes, a different percentage of methanol, $\mathrm{HCl}$ and $\mathrm{H}_{2} \mathrm{O}$ mixtures were taken and preliminary tests were carried out. Figure 1 and Figure 2 show spectra of concentrated and diluted arbutus fruit and leaf extracts extracted in solvents used in different proportions. 
When spectra were compared, it was seen that the highest absorbance values were taken in extractions with solvents containing $80 \%$ Methanol $+\mathrm{H}_{2} \mathrm{O}$ and containing $80 \%$ Methanol $+0.50 \% \mathrm{HCl}+$ Water. As a result of the preliminary trials made with methanol-water mixtures prepared in different percentages, it was decided to use $80 \%$ methanol solution for arbutus leaves and $80 \%$ methanol solution containing $0.5 \% \mathrm{HCl}$ for fruits. It has been seen that the duration of the extraction process is sufficient to apply as 25 minutes. All prepared samples were used after filtering and dilution where necessary.

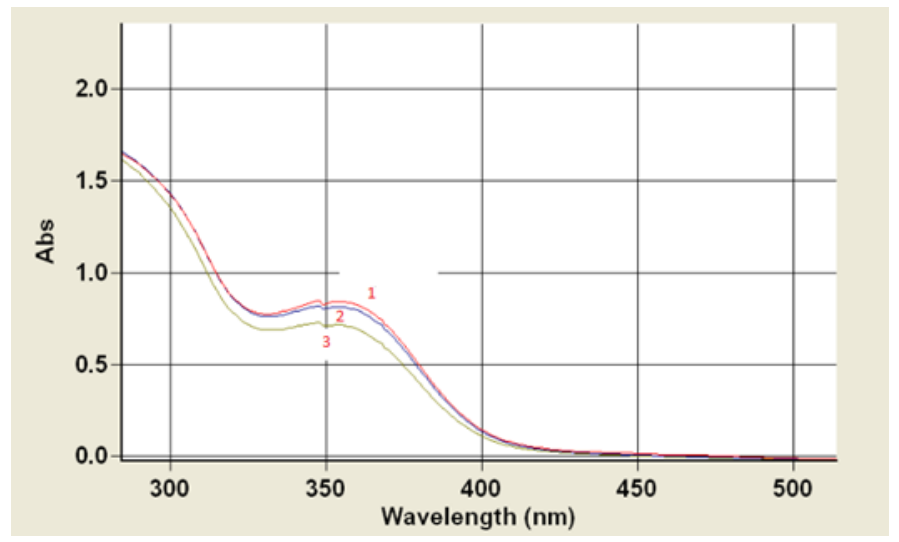

Figure 1. UV spectra of Arbutus Unedo L. extracts containing different $\mathrm{MeOH}$ media.
1: $80 \% \mathrm{MeOH}$
2: $70 \% \mathrm{MeOH}$
3: $50 \% \mathrm{MeOH}$

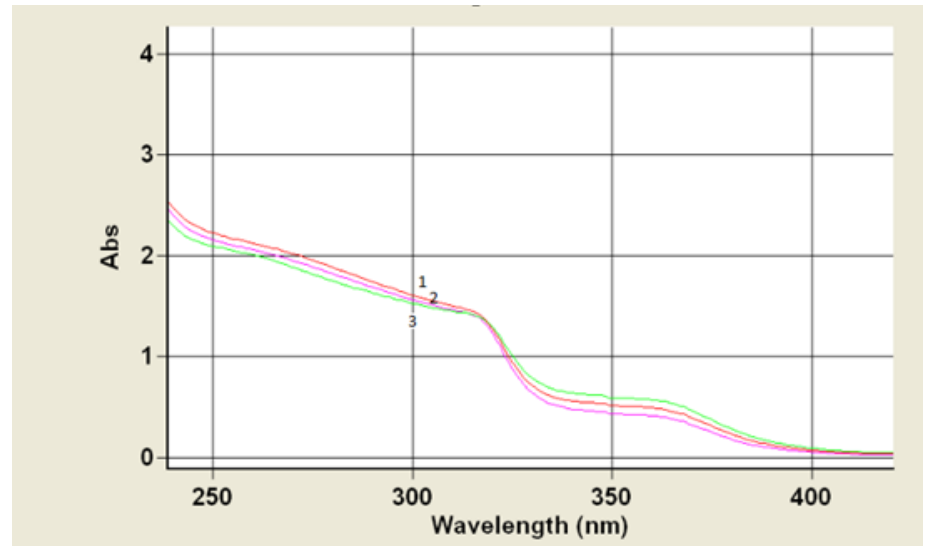

Figure 2. UV spectra of Arbutus Unedo L. extracts containing different $\mathrm{MeOH}+\mathrm{HCl}$ media.
1: $80 \% \mathrm{MeOH}$ containing $0.5 \% \mathrm{HCl}$
2: $80 \% \mathrm{MeOH}$ containing $2.0 \% \mathrm{HCl}$
3: $80 \% \mathrm{MeOH}$ containing $1.0 \% \mathrm{HCl}$

\subsection{Antioxidant activity results}

Two different solvents (applied to the samples were also used for the standards to determine whether the standards had effects in different solvent environments. The trolox used as standard in CUPRAC, ABTS and FRAP methods are solved in different solvents to create calibration curves. The correct equations (y: absorbance, C: concentration), correlation coefficients (R) and linear ranges of the calibration plots drawn between concentration and absorbance were made by diluting at appropriate concentration ranges. The same application was applied to Gallic acid, which is used as standard in the Folin-Ciocalteu method. Linear range, molar absorption and correlation coefficients of linear calibration equations obtained from calibration curves according to CUPRAC [20], ABTS [21], FRAP [22,23], FOLIN-CIOCALTEU [24-26] methods using different proportions are given in Table 1. 
In the standard deviation calculations of antioxidant capacity determination methods, each sample was measured with 5 replicates. Averages and standard deviations are calculated from these data and results are given.

Table 1. For different methods, linear calibration equations and correlation coefficients, molar absorption coefficients of Trolox and Gallic acid in different solvents.

\begin{tabular}{lccc}
\hline Method Names & $\mathbf{R}^{2}$ & $\begin{array}{c}\text { Linear Range } \\
(\mathbf{m o l} / \mathbf{L})\end{array}$ & $\begin{array}{c}\text { Molar absorption coefficient } \\
(\varepsilon)\end{array}$ \\
\hline CUPRAC I & 0.9997 & $5.00 \times 10^{-6}-2.50 \times 10^{-5}$ & $1.60 \times 10^{4}$ \\
CUPRAC II & 0.9988 & $5.00 \times 10^{-6}-2.50 \times 10^{-5}$ & $1.25 \times 10^{-5}$ \\
ABTS I & 0.9988 & $3.30 \times 10^{-6}-3.00 \times 10^{-5}$ & $3.63 \times 10^{4}$ \\
ABTS II & 0.9997 & $3.30 \times 10^{-6}-3.00 \times 10^{-5}$ & $2.98 \times 10^{4}$ \\
FRAP I & 1.0000 & $2.94 \times 10^{-6}-1.18 \times 10^{-5}$ & $4.62 \times 10^{4}$ \\
FRAP II & 0.9990 & $2.94 \times 10^{-6}-1.18 \times 10^{-5}$ & $4.62 \times 10^{4}$ \\
Folin-Ciocalteu I & 0.9991 & $4.21 \times 10^{-6}-2.10 \times 10^{-5}$ & $2.80 \times 10^{4}$ \\
Folin-Ciocalteu II & 0.9994 & $4.21 \times 10^{-6-2.10 \times 10^{-5}}$ & $3.26 \times 10^{4}$ \\
\hline
\end{tabular}

1: $\mathrm{MeOH} / \mathrm{H}_{2} \mathrm{O}(4: 1, \mathrm{v} / \mathrm{v}) ; 2: \mathrm{MeOH} / \mathrm{H}_{2} \mathrm{O} / \mathrm{HCl}$ (8:1.95:0.05, v/v); a: Trolox; b: Gallic acid

In this study, CUPRAC, ABTS and FRAP methods were selected spectrophotometrically for total antioxidant capacity determination and experimental results were compared (Table 2). The total amount of phenolic substances in the Arbutus unedo L. were determined by Folin-Ciocalteu method and their values are given in Table 2. The results were calculated from the calibration curve drawn using trolox and gallic acid as the standard substances and was given as milimolar trolox equivalents (TEAC); mMol trolox/g sample and as mmol gallic acid, GAE/g sample.

Table 2. Results of total antioxidant capacity and total amount of phenolic substances determined with fruit and leaf of Arbutus unedo L. according to different methods and standards prepared in different solvent environments.

\begin{tabular}{|c|c|c|c|c|}
\hline \multirow[t]{2}{*}{ Method Names } & \multicolumn{4}{|c|}{$\begin{array}{c}\text { (mmol trolox TEAC/g sample for CUPRAC, ABTS, FRAP) } \\
\text { (mmol gallic acid GAE/g sample for Folin-Ciocalteau) }\end{array}$} \\
\hline & & (Fruit+MeOH)) & (Fruit+HCl+MeOH) & $($ Leaf $+\mathrm{MeOH})$ \\
\hline \multirow[t]{2}{*}{ CUPRAC } & $1^{\mathrm{a}}$ & $0.2395 \pm 0.0046$ & $0.4527 \pm 0.0057$ & $0.0777 \pm 0.0069$ \\
\hline & $2^{\mathrm{a}}$ & $0.1772 \pm 0.0046$ & $0.3350 \pm 0.0057$ & $0.0575 \pm 0.0069$ \\
\hline \multirow[t]{2}{*}{ ABTS } & $1^{\mathrm{a}}$ & $0.0936 \pm 0.0052$ & $0.1058 \pm 0.0018$ & $0.0472 \pm 0.0012$ \\
\hline & $2^{a}$ & $0.1047 \pm 0.0052$ & $0.1183 \pm 0.0018$ & $0.0506 \pm 0.0012$ \\
\hline \multirow[t]{2}{*}{ FRAP } & $1^{\mathrm{a}}$ & $0.2805 \pm 0.0093$ & $0.3252 \pm 0.0024$ & $0.1016 \pm 0.0080$ \\
\hline & $2^{a}$ & $0.2893 \pm 0.0093$ & $0.3355 \pm 0.0024$ & $0.1048 \pm 0.0080$ \\
\hline Folin- Ciocalteu & $1^{b}$ & $7.9435 \pm 0.0035$ & $4.4176 \pm 0.0066$ & $4.3918 \pm 0.0045$ \\
\hline
\end{tabular}

1: $\mathrm{MeOH} / \mathrm{H}_{2} \mathrm{O}(4: 1, \mathrm{v} / \mathrm{v}) ; 2: \mathrm{MeOH} / \mathrm{H}_{2} \mathrm{O} / \mathrm{HCl}(8: 1.95: 0.05, \mathrm{v} / \mathrm{v})$;

a: Trolox; TEAC ; b: GAE

As a result of the analysis, the total antioxidant capacity ranking obtained from experimental data from Arbutus unedo L. samples extracts is briefly as shown below.

CUPRAC METHOD

ABTS METHOD

FRAP METHOD

FOLIN-CIOCALTEU METHOD : Fruit + A $>$ Fruit + B $>$ Leaf + A 
The values obtained for the trolox prepared in the methanol-water mixture and methanol-water-acid are given in Figure 4. It is seen that the extracts containing methanol-acid-water have high antioxidant activities calculated according to the trolox dissolved in methanol-water-acid. Here, it can be said that the low amount of acid is effective in increasing the antioxidant activity.
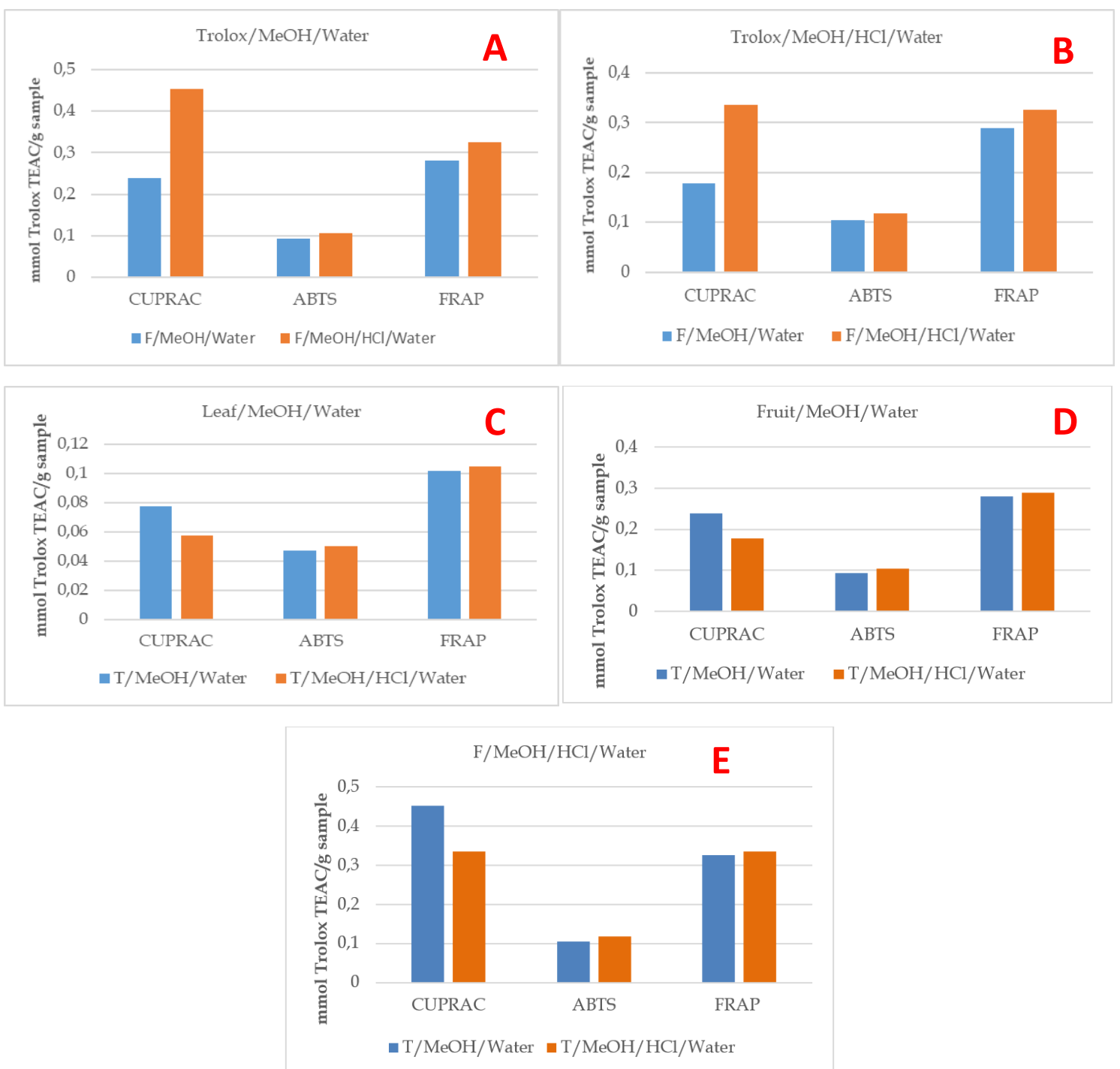

Figure 3. Column charts (A, B, C, D, E, ) of the values obtained for trolox prepared in different proportions and for samples with different solvents.

When we look at the A and B graphs in Figure 3, it is seen that the extracts of the acid-added samples lead to a slightly higher antioxidant activity than the acid-free in the extraction processes where we keep the samples stable. This difference is more pronounced in the CUPRAC method. When the antioxidant activity values of the experiments prepared by preparing trolox with and without acid used in calibration were compared, antioxidant activities were found to be lower in the acidic trolox graph (B) compared to acid free (A). It is seen that the extracts containing methanol-acid-water have high antioxidant activities calculated according to the trolox dissolved in methanol-water-acid. When the antioxidant values of leaf and fruit extracts extracted with only methanol were compared with methanol containing acid, the values decreased in CUPRAC method according to TEAC calculation, while the values increased in ABTS and FRAP methods (C, $\mathrm{D}, \mathrm{E})$. It is clearly seen here in the $\mathrm{D}$ and $\mathrm{E}$ graphs that the addition of acid to the extracts increases the detection level higher. Here, it can be said that the low amount of acid is effective in increasing the antioxidant activity. This difference is much more obvious when graphs $\mathrm{A}$ and $\mathrm{B}$ are compared with $\mathrm{D}$ and $\mathrm{E}$.

In the Folin-Ciocalteu Reagent method, it was observed that the total phenol content of the fruit extracted with methanol gave more results than the methanolic acid mixture. It was observed in Figure 4 that 
the total phenol content of the leaf was close to the fruit in the methanolic acid mixture. In this method, unlike the antioxidant activity methods, it was determined that only fruit extracts containing methanol contain more phenol. Our results of total phenol content for fruits and leaf of Arbutus unedo L. were found as follows; $7.9435 \pm 0.0035 \mathrm{mg} \mathrm{GAE} / \mathrm{g}$ in $\mathrm{MeOH}+$ Water; $4.4176 \pm 0.0066 \mathrm{mg} \mathrm{GAE} / \mathrm{g}$ in $\mathrm{MeOH}+\mathrm{HCl}+\mathrm{Water}$; for leaf $4.3918 \pm 0.0045 \mathrm{mg} \mathrm{GAE} / \mathrm{g}$ in $\mathrm{MeOH}+$ Water.

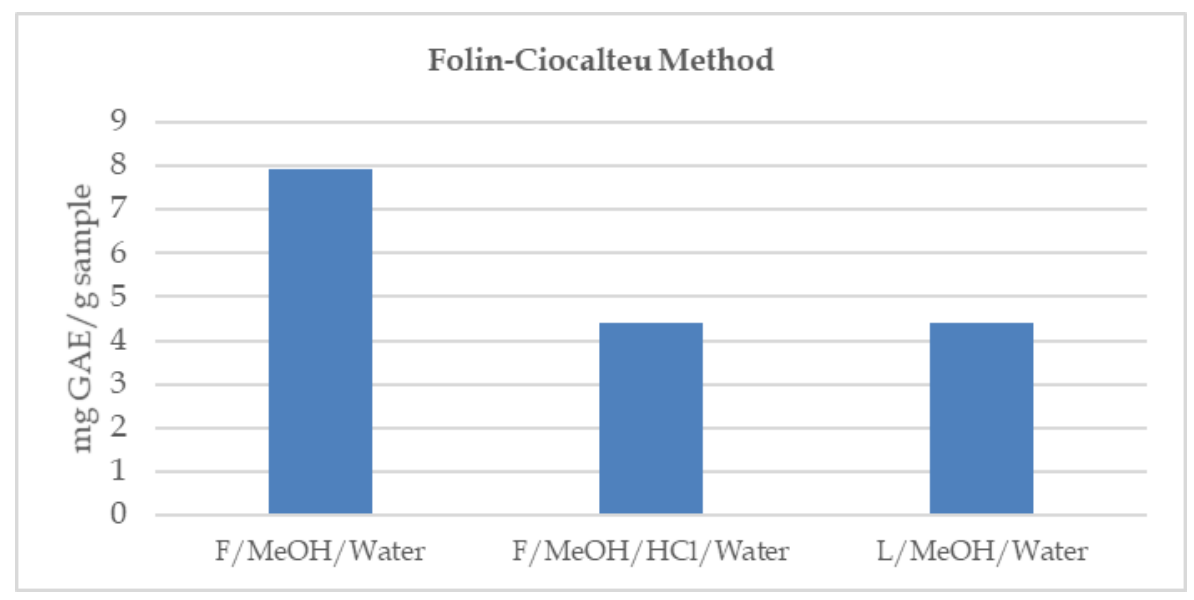

Figure 4. Quantification of total phenolic contents; Folin-Ciocalteu Reagent (FCR) method.

\subsection{Trace elements results}

As a result of the analysis of the reference material used for the reliability of the results, it was determined that the basic content was compatible with the certified values. Certified values, obtained values and recovery results for NIST-SRM 1515, the data of the calibration curves are given in Table 3.

Table 3. Recovery results for NIST-SRM 1515 and the data of the calibration curves parameters for Al, Cd, $\mathrm{Cu}, \mathrm{Cr}, \mathrm{Fe}, \mathrm{Mn}, \mathrm{Pb}, \mathrm{Zn}$ elements.

\begin{tabular}{|c|c|c|c|c|}
\hline Element Name & $\mathbf{R}^{2}$ & \multicolumn{2}{|c|}{$\begin{array}{c}\text { (NIST SRM 15!5) } \\
\text { Certified Value - Observed Value }\end{array}$} & Recovery (\%) \\
\hline $27 \mathrm{Al}$ & 0.999985 & 286 & 282.92 & 98.92 \\
\hline $111 \mathrm{Cd}$ & 0.999864 & 0.013 & 0.012 & 92.30 \\
\hline $52 \mathrm{Cr}$ & 0.999993 & 0.3 & 0.282 & 94.00 \\
\hline $63 \mathrm{Cu}$ & 0.999993 & 5.69 & 5.305 & 93.10 \\
\hline $56 \mathrm{Fe}$ & 0.999847 & 83 & 80.9 & 97.46 \\
\hline $55 \mathrm{Mn}$ & 0.999966 & 54.1 & 52.59 & 97.57 \\
\hline $208 \mathrm{~Pb}$ & 0.999955 & 0.47 & 0.453 & 96.38 \\
\hline $66 \mathrm{Zn}$ & 0.999869 & 12.45 & 11.4 & 91.56 \\
\hline
\end{tabular}

Analysis were made by taking average values of all samples in 3 repetitions $(n=3)$. Results are given in $\mu \mathrm{g} / \mathrm{g}$ sample in Table 4.

Table 4. Trace element concentration for fruit and leaf in Arbutus unedo L. by using ICP-MS.

\begin{tabular}{ccccccccc}
\hline \multicolumn{10}{c}{ (Xort \pm SD) $(\boldsymbol{\mu g} / \mathrm{g})$} \\
\hline Fruit & $1234.90 \pm 65.40$ & $\mathbf{C d}$ & $\mathbf{C r}$ & $\mathbf{C u}$ & $\mathbf{F e}$ & Mn & Pb & Zn \\
Leaf & $631.25 \pm 25.25$ & $<0.000$ & $<0.000$ & $98.05 \pm 17.50$ & $550.12 \pm 35.04$ & $13.78 \pm 1.63$ & $<0.000$ & $421.63 \pm 21.32$ \\
\hline
\end{tabular}




\section{DISCUSSION}

In recent years, the discovery of medicinal plants used in alternative and supportive therapy as well as in the content of some drugs has begun to be accepted as an important source of new molecules with strong antioxidant properties. As a natural antioxidant source, it is seen from studies that Arbutus Unedo L. contains many bioactive components, especially due to its rich content of antioxidants, it can have a protective effect against many diseases, especially cancer and cardiovascular diseases. The solvent effect on the chemical behavior of antioxidant compounds is an essential parameter. Antioxidants don't show similar antioxidant activity in hydrophilic and lipophilic environments. On the contrary, their antioxidant properties differ with the change of solvent media. Solvent type and polarity affect hydrogen atom and electron transfer, which are important in antioxidant capacity measurements. There are many studies in the literature about the solvent effect on antioxidant capacity. Although it has a solvent effect in frequently used methods such as ORAC, ABTS, FRAP and DPPH, the type and properties of the solvent affect each method differently. Jimenez and Saura-Calixto observed that the capacity observed in the aqueous solution for gallic acid-catechin mixture in different solvents was $40 \%$ higher than that observed in methanol-water, and the capacity increased as the water ratio increased in methanol-water mixtures $[27,28]$. In other words, an increase in antioxidant capacity is observed due to the increase in solvent polarity. Therefore, when comparing antioxidant capacities, solutions or extracts prepared with the same solvents should be measured. Otherwise, the results can be very different and it is not meaningful to compare methods directly [29]. There are more than 20 methods given in the literature for the measurement of antioxidant capacity. In the case of determining the antioxidant capacities of plants and the total phenolic content of the plant extracts, the results in the literature clearly show that antioxidant activity is highly dependent on the chosen method of determination and a complete correlation may not be observed between the observed antioxidant activity (or capacity) [30,31,32].

CUPRAC values for polyphenols are similar to TEAC values. CUPRAC reagent, like ABTS and DPPH, is more stable and easier to obtain than chromogenic radical reagents. The redox reaction giving colored $\mathrm{Cu}$ (I)-Nc chelate is not affected by parameters such as air, sunlight, humidity and $\mathrm{pH}$ [20].

Fortelazas et al. found the total phenolic content as $(16.46 \pm 3.66 \mathrm{mg} \mathrm{GAE} / \mathrm{g})$ according to the FolinCiocalteu method, and the antioxidant capacity for fruit of Arbutus unedo L. (11.66 $\pm 2.01 \mathrm{mmol}$ TE/100 g) according to the ORAC method [13]. Orak et al. found that on the determination of antioxidant activity and phenol content of fresh and freeze-dried strawberry tree (Arbutus unedo L.) fruits in hot air, 1,1-diphenyl-2picrylhydrazyl scavenging activity $(82.16 \pm 0.34 \%)$, total phenolic content in dried fruits was $7.62 \pm 1.09 \mu \mathrm{g}$ GAE/g extract). DPPH activity was found to be $(94.03 \pm 1.18 \%)$ in fresh fruits. They found that fresh fruits had higher antioxidant activity [9]. In another study, DPPH radical scavenging activities were found $0.087 \pm 0.007$ $\mathrm{mg} / \mathrm{mL}$ for leaf, and $0.790 \pm 0.016 \mathrm{mg} / \mathrm{mL}$ for fruit extracts of Arbutus unedo L. by Mendes et al. [40].

Total phenol content and antioxidant power of Arbutus unedo L. fruits were compared between ripe and immature fruits. Total phenol contents of ripe, immature and intermediate fruits were $60,108,111 \mathrm{mg} \mathrm{GAE} / \mathrm{g}$ dry fruit. DPPH radical scavenging activities found for ripe and intermediate fruits $\mathrm{EC}_{50}$ values $(0.25 \pm 0.02$ $\mathrm{mg} / \mathrm{mL})$ and $(1.09 \pm 0.05 \mathrm{mg} / \mathrm{mL})$ respectively [41]. According to ABTS method, they found antioxidant capacity (21.10 $\pm 0.01 \mathrm{mM}$ Trolox eq/g) and total phenol content (2.42 $\pm 0.01 \mathrm{mg}$ GAE/g) in fresh fruits [42]. Moualek et al. for Arbutus unedo L. antioxidant activity determination, according to the FRAP method, they found that its reducing power $\mathrm{IC}_{50}=(56.72 \pm 2.79) \mathrm{mg} / \mathrm{mL}$. In DPPH method, $\mathrm{IC}_{50}$ value for anhydrous extract with respect to ascorbic acid was $(2.359 \pm 0.091) \mathrm{mg} / \mathrm{mL}$, also for the aqueous extract, this value was found to be higher than $\mathrm{IC}_{50}[(7.956 \pm 0.278) \mathrm{mg} / \mathrm{mL}$. They found the total phenolic content for the anhydrous extract as [(207.84 \pm 15.03$) \mathrm{mg} \mathrm{GAE} / \mathrm{g}$ of extract] [43].

While it is possible to use all methods in determining the antioxidant capacity of a plant, the molecular diversity of the antioxidant substances in the sample can always prevent a linear relationship between these methods. Therefore, it may not be appropriate to decide on the antioxidant capacity of the plant using a single method. The analytical methods used in the measurements and the conditions under which the analysis occurs may cause different results for the same food type [19].

Arbutus unedo L. fruits are the rich source of minerals. So, now and in the future, it will have a growing value for human nutrition. It is very important to know the proportions of vital trace elements in food in metabolism. Özcan and Hacıseferoğulları determined the mineral content of Arbutus unedo L. by ICP-AES. They found the results as Al $20.11 \pm 2.69 \mathrm{mg} / \mathrm{kg}$, As $10.58 \pm 6.47 \mathrm{mg} / \mathrm{kg}$, B $16.03 \pm 2.12 \mathrm{mg} / \mathrm{kg}$, Ca $4959.02 \pm$ $150 \mathrm{mg} / \mathrm{kg}, \mathrm{Cd} 0.19 \pm 0.05 \mathrm{mg} / \mathrm{kg}$, Cr $2.41 \pm 0.96 \mathrm{mg} / \mathrm{kg}, \mathrm{Cu} 1.65 \pm 0.41 \mathrm{mg} / \mathrm{kg}$, Fe $12.15 \pm 1.11 \mathrm{mg} / \mathrm{kg}, \mathrm{Ga} 0.47$ $\pm 0.43 \mathrm{mg} / \mathrm{kg}, \mathrm{K} 14909.08 \pm 1687 \mathrm{mg} / \mathrm{kg}, \mathrm{Li} 0.94 \pm 0.15 \mathrm{mg} / \mathrm{kg}, \mathrm{Mg} 1315.57 \pm 129.19 \mathrm{mg} / \mathrm{kg}, \mathrm{Mn} 4.44 \pm 0.55$ $\mathrm{mg} / \mathrm{kg}$, Na $701.26 \pm 80 \mathrm{mg} / \mathrm{kg}$, Ni $0.13 \pm 0.14 \mathrm{mg} / \mathrm{kg}, \mathrm{P} 3668.56 \pm 339.69 \mathrm{mg} / \mathrm{kg}, \mathrm{Pb} 0.51 \pm 0.04 \mathrm{mg} / \mathrm{kg}$, Sr 5.10 
$\pm 0.80 \mathrm{mg} / \mathrm{kg}$, Ti $0.16 \pm 0.26 \mathrm{mg} / \mathrm{kg}, \mathrm{V} 16.63 \pm 4.27 \mathrm{mg} / \mathrm{kg}, \mathrm{Zn} 8.09 \pm 0.96 \mathrm{mg} / \mathrm{kg}$. They stated that they found the element concentrations of fruits very high [7]. Miguel et al. made a rewiev about Arbutus unedo L. fruits collected in the Northeast Anatolia region of Turkey's which including the work done on the content of minerals and trace elements contents, they gave the results as follows: $\mathrm{K}(119 \mathrm{mg} / 100 \mathrm{~g}) ; \mathrm{P}(12.6 \mathrm{mg} / 100 \mathrm{~g})$; Ca $(12 \mathrm{mg} / 100 \mathrm{~g}) ; \mathrm{Mg}(9.1 \mathrm{mg} / 100 \mathrm{~g}) ; \mathrm{Fe}(1.25 \mathrm{mg} / 100 \mathrm{~g}) ; \mathrm{Cu}(0.088 \mathrm{mg} / 100 \mathrm{~g}) ; \mathrm{Zn}(2.602 \mathrm{mg} / 100 \mathrm{~g}) ; \mathrm{Mn}$ $(0.197 \mathrm{mg} / 100 \mathrm{~g}) ;$ In the northwest of Turkey's $(11.346 \mathrm{mg} / \mathrm{kg}$ and 13,661,45 mg/ $\mathrm{kg}) ; \mathrm{Ca}(5673.39 \mathrm{mg} / \mathrm{kg}$ and $5475.62 \mathrm{mg} / \mathrm{kg}) ; \mathrm{P}(4278.38 \mathrm{mg} / \mathrm{kg}$ and $4554.91 \mathrm{mg} / \mathrm{kg}) ; \mathrm{Mg}(1691.46 \mathrm{mg} / \mathrm{kg}$ and $1931.49 \mathrm{mg} / \mathrm{kg}) ; \mathrm{Na}(1136.79$ $\mathrm{mg} / \mathrm{kg}$ and $1034.53 \mathrm{mg} / \mathrm{kg}$ ). In the same rewiev, a study on the mineral composition fruit of Arbutus unedo L. which collected from Mersin ( Turkey): Ca (4959 mg/kg), K (14.909 mg/kg), Mg (1316 mg/kg), Na (701 $\mathrm{mg} / \mathrm{kg}$ ) and $\mathrm{P}(3669 \mathrm{mg} / \mathrm{kg}$ ) were found while $\mathrm{Cd}, \mathrm{Cu}, \mathrm{Li} \mathrm{Mn}, \mathrm{Ni}, \mathrm{Pb}$ and $\mathrm{Sr}$ were found in very low amounts. In this rewiev, in the Arbutus unedo L. samples collected from three different seasons and from two places with different environmental conditions (Madrid, center of Spain; and Cáceres, west of Spain) a difference was found in the mineral composition of the fruit of the strawberry tree. According to the results of the authors, they stated that the harvest year $\mathrm{K}, \mathrm{Mg}, \mathrm{Cu}, \mathrm{Fe}, \mathrm{Mn}$ significantly affected the fruit content.[11]. Vidrih et al. determined the mineral contents for Arbutus Unedo L. by AAS. As a result, they found the amount of elements as follows: $\mathrm{K}(118.61 \pm 10.79(\mathrm{mg} / 100 \mathrm{~g} \mathrm{fw}), \mathrm{Na}(20.63 \pm 1.64 \mathrm{mg} / 100 \mathrm{~g} \mathrm{fw}), \mathrm{Ca}(36.05 \pm 7.08 \mathrm{mg} / 100 \mathrm{~g} \mathrm{fw}), \mathrm{Mg}$ $(9.66 \pm 1.28 \mathrm{mg} / 100 \mathrm{~g} \mathrm{fw})$, Fe $(1.29 \pm 0.06 \mathrm{mg} / 100 \mathrm{~g} \mathrm{fw}), \mathrm{P}(19.99 \pm 2.77 \mathrm{mg} / 100 \mathrm{~g} \mathrm{fw}), \mathrm{Zn}(0.45 \pm 0.10 \mathrm{mg} / 100$ $\mathrm{g} \mathrm{fw}), \mathrm{Mn}(<0.99 \mathrm{mg} / 100 \mathrm{~g} \mathrm{fw}), \mathrm{Cr}(<0.99 \mathrm{mg} / 100 \mathrm{~g} \mathrm{fw}), \mathrm{Ni}(<0.10 \mathrm{mg} / 100 \mathrm{~g} \mathrm{fw}), \mathrm{Pb}(<1.32 \mathrm{mg} / 100 \mathrm{~g} \mathrm{fw}), \mathrm{Cd}$ $(<0.10 \mathrm{mg} / 100 \mathrm{~g} \mathrm{fw})$. They obtained from the study were in agreement with other articles [44].

According to WHO standards, each element must be within certain limits in various products and metabolism [33]. Our study, the trace element concentrations were examined (Table 4), it was found that the element concentrations in the leaves were lower than in the fruits. $\mathrm{Al}$ in fruit is $1234.90 \pm 65.40 \mu \mathrm{g} / \mathrm{g}$ and leaf $631.25 \pm 25.25 \mu \mathrm{g} / \mathrm{g}$; $\mathrm{Cu}$ in fruit is $132.36 \pm 12.40 \mu \mathrm{g} / \mathrm{g}$ and $98.05 \pm 17.50 \mu \mathrm{g} / \mathrm{g}$ in leaf; Fe in fruit is $1410.25 \pm 88.52$ $\mu \mathrm{g} / \mathrm{g}$ and $550.12 \pm 35.04 \mu \mathrm{g} / \mathrm{g}$ in leaf; $\mathrm{Mn}$ in fruit is $190.09 \pm 6.30 \mu \mathrm{g} / \mathrm{g}$ and $13.78 \pm 1.63 \mu \mathrm{g} / \mathrm{g}$ in leaf; $\mathrm{Zn}$ in fruit is $745.54 \pm 86.12 \mu \mathrm{g} / \mathrm{g}$ and $421.63 \pm 21.32 \mu \mathrm{g} / \mathrm{g}$ in leaf; $\mathrm{Cd}$ in fruit is $14.40 \pm 0.75 \mu \mathrm{g} / \mathrm{g}$; $\mathrm{Cr}$ in fruit is $1.60 \pm 0.025$ $\mu \mathrm{g} / \mathrm{g}$; $\mathrm{Pb}$ in fruit is $32.62 \pm 1.60 \mu \mathrm{g} / \mathrm{g}$. While $\mathrm{Cd}, \mathrm{Cr}$ and $\mathrm{Pb}$ were detected in the fruit within the limits, it was found below the dedection limits in the leaf.

\section{CONCLUSION}

The fruits of Arbutus unedo L. are a good source of antioxidants and contain high amounts of sugar. Considering that antioxidant and vitamin deficiencies can lead to significant deterioration in metabolism, it is thought that the damages of free radicals in the body can be prevented with nutritional supplements containing vitamins and antioxidants in addition to healthy nutrition. In conclusion, according to our study, in vitro antioxidant activity determination with Strawberry tree (Arbutus unedo L.) was found suitable according to the literature, in which the fruits and leaves of the plant have antioxidant properties [11]. When the methods used were compared among themselves, it was found that a single determination method would give limited information about the antioxidant power, therefore, several of them should be used together and different solvent ratios should be tried in extraction processes. A different in the mineral composition of the fruit of the Arbutus unedo L. can be seen when compared with other articles. The reason for this can be said that fruits collected in different seasons, the region where it is grown, the soil, water and also the climate conditions are effective. In addition, it was determined that the trace elements analyzed were below the detection limits according to WHO standards [33]. Considering the our experimental data, Arbutus unedo L. is a good source of antioxidants and minerals, therefore its use as a nutritional supplement should not be overlooked.

\section{MATERIALS AND METHODS}

\subsection{Plant material}

In our study, fruits and leaves were collected from the Thermal district of Yalova province in NovemberDecember. The plant identification was made by Prof. Dr. Ertan TUZLACI from Marmara University Faculty of Pharmacy, Department of Pharmaceutical Botany, and it is stored with MARE 15675 in the Herbarium of Marmara University Faculty of Pharmacy. Picking the berries, it was stored in the freezer at $-20^{\circ} \mathrm{C}$. Arbutus unedo L. leaves were separated from their branches one by one, and dried in a shaded area. After drying, it was stored in a closed box that was not exposed to sun at room temperature. 


\subsection{Chemicals, reagents and devices}

Devices used in this study; Libror AEX-2006 analytical balance, LC 30 ultrasonic bath for extraction processes and chemical dissolution, Kika labortechnik FS125 basic mixer for mixing solutions, Arçelik A+ freezer for in freezing storage of fruit samples, Millipore Simpak 1 Synergy 185 water system, Bergoff Speedwave Microwave Oven, Agilent Technologies ICP-MS 7700, and Shimadzu (UV-1601) UV-Vis spectrophotometer were used. Trolox (6-Hydroxy-2,5,7,8-tetramethylchroman-2-carboxylic Acid), ABTS (2, 2'azinobis (3-ethylbenzothiazoline-6-sulfonic acid), Neocuproine(2,9-Dimethyl-1,10-phenanthroline), Methanol, Ethanol, $\mathrm{HCl}, \mathrm{CuSO}_{4} \cdot 5 \mathrm{H}_{2} \mathrm{O}, \mathrm{FeCl}_{3} \cdot 6 \mathrm{H}_{2} \mathrm{O}, \mathrm{CH}_{3} \mathrm{COOH}, \mathrm{Na}_{2} \mathrm{CO}_{3}$, (Merck KGaA Darmstadt, Germany), 2,4,6-Tris(2-pyridyl)-s-triazine (TPTZ), $\quad \mathrm{K}_{2} \mathrm{~S}_{2} \mathrm{O}_{8}, \quad \mathrm{CH}_{3} \mathrm{COONa} .3 \mathrm{H}_{2} \mathrm{O}, \quad$ Potassium sodium tartrate tetrahydrate $\left(\mathrm{NaKC}_{4} \mathrm{H}_{4} \mathrm{O}_{6}\right)$, Folin-Ciocalteu Reagent(FCR) $\left[3 \mathrm{H}_{2} \mathrm{O} . \mathrm{P}_{2} \mathrm{O}_{5} .13 \mathrm{WO}_{3} .5 \mathrm{MoO}_{3} \cdot 10 \mathrm{H}_{2} \mathrm{O}\right]$, were obtained from Sigma-Aldrich.

\subsection{Preparation of plant extracts for antioxidant capacities}

Fruit and leaf extracts of Arbutus Unedo L. whose antioxidant capacities will be determined, were prepared daily. The first extraction were carry out with contains $80 \%$ methanol and $0.5 \%$ hydrochloric acid $(80.0 \mathrm{~mL}$ methanol $+19.5 \mathrm{~mL}$ distilled water $+0.5 \mathrm{~mL}$ hydrochloric acid; $(8: 1.95: 0.05 ; \mathrm{v} / \mathrm{v}))$ solutions and second extraction were carry out with contains $80 \%$ methanol $(80.0 \mathrm{~mL}$ methanol $+20.0 \mathrm{~mL}$ distilled water; $4: 1, \mathrm{v} / \mathrm{v}$ ) solutions. After the dissolving at the room temperature frozen fruit was weighed $1.30 \mathrm{~g}$ and dried leaf was weighed $0.50 \mathrm{~g}$ for each trial. First solvent containing $10.0 \mathrm{~mL}$ of $80 \%$ methanol and $0.5 \%$ hydrochloric acid was added to the weighed fruits and leaves, and kept in ultrasonic bath for 15 minutes at $30^{\circ} \mathrm{C}$. Then, the extracts were filtered off over Whatman No.1 paper, another $10.0 \mathrm{~mL}$ of solvent was added to the fruit and leaves. After these processes were repeated 3 stages in totally 45 minutes for each solvent helding in the closed flask, the extracts were combined.

\subsection{Cuprac reducing antioxidant capacity (CUPRAC) method}

This antioxidant capacity method, developed by Apak et al., was called "Copper (II) ion reduction antioxidant capacity method" and was named as CUPRAC method for short [22]. $1.0 \mathrm{~mL} 0.01 \mathrm{M} \mathrm{CuCl}_{2} \cdot 2 \mathrm{H}_{2} \mathrm{O}$ solution, $1.0 \mathrm{~mL}$ 0,0075 M Neocuproine solution (in 96\% ethyl alcohol) (2,9-dimethyl-1,10-phenanthroline) and $1.0 \mathrm{~mL}_{1.0} \mathrm{M} \mathrm{CH}_{3} \mathrm{COONH}_{4}$ buffer $(\mathrm{pH}=7)$ was added and mixed. Then $1.0 \mathrm{~mL}$ extract was added this mix and vortexed. To complete the redox reaction between $\mathrm{Cu}$ (II)-Nc and antioxidant, the mixture was kept at room temperature for 30 minutes in the dark, and its absorbance at $450 \mathrm{~nm}$ was read against the reference solution. The CUPRAC results were calculated from the calibration curve drawn using trolox as the standard substance and was given as milimolar trolox equivalents (TEAC), mMol Trolox/g sample.

\subsection{The ABTS radical cation assay / (TEAC)}

TEAC/ABTS method, expressed as the trolox equivalent antioxidant capacity, was first developed by Miller et al. [21,34]. ABTS (2,2'-Azino-bis (3-ethylbenzothiazoline-6-sulfonic acid), at 7.0 mM concentration, was prepared by dissolving this compound in water and adding $\mathrm{K}_{2} \mathrm{~S}_{2} \mathrm{O}_{8}$ to this solution such that the final persulphate concentration in the mixture is $2.45 \mathrm{mM}$. The obtained ABTS ${ }^{+}$radical solution was left in the dark and at room temperature for 12-16 hours to be ready for use. The blue-green ABTS ${ }^{+}$radical solution, which was ready for use after standing, was diluted at a rate of 1:50 with ethyl alcohol. $4 \mathrm{~mL} \mathrm{EtOH}$ was added to the $1.0 \mathrm{~mL}$ ABTS ${ }^{+}$solution, and the absorbance values at the end of the first and sixth minutes at $734 \mathrm{~nm}$ were recorded. Then, $3.0 \mathrm{~mL}$ ABTS.+ solution and $0.5 \mathrm{~mL}$ solvent were added $0.5 \mathrm{~mL}$ sample and absorbance values were measured at the same wavelength at the end of the 6 th minute against the reference solution. $\Delta \mathrm{A}$ values were obtained by subtracting the absorbance values of the sample solution from the absorbance value of the ABTS Radical.

\subsection{Ferric reducing/antioxidant power (FRAP) assay}

The ability of ferric reducing of samples was evaluated using the FRAP method developed by Benzie and Strain [22,34]. It was weighed from $\mathrm{FeCl}_{3} \cdot 6 \mathrm{H}_{2} \mathrm{O}$ with a final concentration of $0.02 \mathrm{M}$ and dissolved in 1.0 $\mathrm{M} \mathrm{HCl}$. The final concentration of the TPTZ solution was prepared using $96 \%$ ethyl alcohol to be $0.01 \mathrm{M}$. To prepare the FRAP reagent, $0.3 \mathrm{M} \mathrm{CH}_{3} \mathrm{COOH} / \mathrm{CH}_{3} \mathrm{COONa} .3 \mathrm{H}_{2} \mathrm{O}$ buffer $(\mathrm{pH}: 3.6), 0.02 \mathrm{M} \mathrm{FeCl}_{3} .6 \mathrm{H}_{2} \mathrm{O}$ solution and $0.01 \mathrm{M}$ TPTZ reagent was prepared by mixing in a $(10: 1: 1 ;(\mathrm{v} / \mathrm{v} / \mathrm{v})$ ratio. $0.4 \mathrm{~mL}$ of extract was added to the prepared $3.0 \mathrm{~mL}$ of FRAP reagent and vortexed. At the end of the 6 th minute, the absorbance values of the samples at $595 \mathrm{~nm}$ were measured against the reference solution. The results were calculated from the calibration curve drawn using trolox as the standard substance and was given as milimolar trolox equivalents (TEAC), mMol Trolox/g sample. 


\subsection{Quantification of total phenolic contents; Folin-Ciocalteu reagent (FCR) method}

The Folin-Ciocalteu reagent (FCR) method by modifying the method was developed by Singleton et al. to measure the total phenolic content of antioxidants [23-25]. We were little modified this method. $0.5 \mathrm{~mL}$ extract was taken in the tube then $0.5 \mathrm{~mL}$ water and $0.25 \mathrm{~mL}$ of Folin-Ciocalteu reagent (diluted 1/3 with distilled water) was added and wixed. Following $5 \mathrm{~min} 2.25 \mathrm{~mL} 2 \% \mathrm{Na}_{2} \mathrm{CO}_{3}$ solution were added to this mix. The mixture was left at room temperature for 60 minutes to keep the formed color stable. Absorbance values were recorded against the reference solution at $760 \mathrm{~nm}$. Total phenolic contents were calculated with the calibration graph of gallic acid and gived as gallic acid equivalents (GAE), (mg GAE/g sample) $[24,25,26,35,36,37,38]$.

\subsection{Preparation of plant extracts for trace elements determination}

Fort the trace element determination, fruit and leaf samples of Arbutus unedo L. were weighed and put into teflon containers to be solubilized in microwave oven (Bergoff). $8.0 \mathrm{~mL}$ of $65 \%$ suprapur $\mathrm{HNO}_{3}$ was added and waited for 5 minutes, then $2.0 \mathrm{~mL}$ of $30 \% \mathrm{H}_{2} \mathrm{O}_{2}$ was added and left for another 5 minutes. The teflon cells were covered and placed in the microwave burning unit after being kept in this way for 20 minutes. The dissolution process was realized by adjusting the temperature and time of the microwave oven program (0$200^{\circ} \mathrm{C}$ ). After the dissolution process is completed, the sample solutions in the cooled teflon cells were filtered into polyethylene containers with the help of blue banded filter paper and completed to $50.0 \mathrm{~mL}$ with ultra pure water. It was stored in a refrigerator at $+4^{\circ} \mathrm{C}$ until analysis.

\subsection{Calibration procedure for trace element analysis}

Analysis of $\mathrm{Al}, \mathrm{Cd}, \mathrm{Cu}, \mathrm{Cr}, \mathrm{Fe}, \mathrm{Mn}, \mathrm{Pb}$ and $\mathrm{Zn}$ elements in the samples was performed using Agilent Technologies ICP-MS 7700 instrument. High purity ICP multi element standart standard stock solutions (NIST) of all elements at a concentration of $1000 \mathrm{mg} / \mathrm{L}$ were used for calibration process. From these standards, intermediate stock solutions were prepared and calibration curves for each element were created. All dilution process were carried out with $2.0 \%$ nitric acid $\left(\mathrm{HNO}_{3}\right)$ and $0.5 \%$ hydrochloric acid $(\mathrm{HCl})$ solutions prepared with ultrapure water. Certified Reference Material (NIST SRM1515 apple leaf) was used in calibration processes for the reliability of the results.

Acknowledgements: This study was supported by the Commission of Marmara University Scientific Research Project BAPKO (SAG-C-YLP-100713-0307).

Author contributions: Concept - G.E.; Design - G.E., T.U.; Supervision - G.E.; Resources - G.E., T.U.; Materials - T.U., G.E.; Data Collection and/or Processing -T.U., G.E.; Analysis and/or Interpretation -G.E., T.U.; Literature Search -G.E., T.U.; Writing - G.E.; Critical Reviews - G.E., T.U.

Conflict of interest statement: The authors declared no conflict of interest in the manuscript.

\section{REFERENCES}

[1] Aeschbach R, Halliwell B, Löliger J, Aruoma OI. The characterization of antioxidants. Food Chem Toxicol. 1995; 33: 601-617. [CrossRef]

[2] Cadenas E, Packer L. Handbook of Antioxidants. Marcel Dekker, New York-Basel. 2002; 0-8247-0547-5.

[3] Fang YZ, Yang S, Wu G. Free radicals, antioxidants, and nutrition. Biochem Mol Biol. 2002 ; 18 (10): $872-879$. [CrossRef]

[4] Kim YJ, Lee KW, Kim D, Lee HJ, Chun Y. Major phenolics in the apple their contribution to the total antioxidant capacity. J Agric Food Chem. 2003; 51(22): 6516-6520. [CrossRef]

[5] P. G. Pietta. Flavonoids as antioxidants. J Nat Prod. 2000; 63(7): 1035-1042. [CrossRef]

[6] Halliwell B, Aruoma OI. DNA damage by oxygen-derived species: Its mechanisms and measurement in mammalian systems. FEBS Letters. 1991; 281: 9-19. [CrossRef]

[7] Özcan MM, Hacıseferoğulları H. The Strawberry (Arbutus unedo L.) fruits: Chemical composition, physical properties and mineral contents. J Food Eng. 2007; 78(3): 1022-1028. [CrossRef]

[8] Laouicha S, Senator A, Kherbache K, Bouriche H. Total phenolic contents and antioxidant properties of algerian Arbutus unedo L. extracts. J Drug Deliv. 2020; 10(3-s):159-168. [CrossRef] 
[9] Orak HH, Aktas T, Yagar H, İsbilir SS, Ekinci N, Sahin FH. Effects of hot air and freeze drying methods on antioxidant activity, colour and some nutritional characteristics of strawberry tree (Arbutus unedo L) fruit. Food Sci Technol Int. 2012; 18(4): 391-402. [CrossRef]

[10] Bouyahya A, Moussaoui NE, Abrini J, Bakri Y, Dakka N. Determination of Phenolic Contents, Antioxidant and Antibacterial Activities of Strawberry Tree (Arbutus unedo L.) Leaf Extracts. Br Biotechnol J. 2016; 14(3): 1-10. [CrossRef]

[11] Miguel MG, Faleiro ML, Guerreiro AC, Antunes MD. Arbutus unedo L.: Chemical and Biological Properties. Molecules. 2014; 19: 15799-15823. [CrossRef]

[12] Pabuçcuoğlu A, Kıvçak B, Baş M, Mert T. Antioxidant activity of Arbutus unedo L. leaves. Fitoterapia. 2003; 74(6): 597599. [CrossRef]

[13] Fortalezas S, Tavares L, Pimpao R, Tyagi M, Pontes V, Alves PM, McDougall G, Stewart D, Ferreira RB, Santos CN. Antioxidant properties and neuroprotective capacity of strawberry tree fruit (Arbutus unedo). Nutrients. 2010; 2: 214229. [CrossRef]

[14] Karıas GA, Euerby MR, Waigh RD. Constituents of the stems of Arbutus unedo L. Planta Medica. 1986; 53(2): 223224.

[15] Guimaraes R, Barros L, Duenas M, Carvalho AM, Queiroz MJRP, Celestino Santos-Buelga C, Ferreira ICFR. Characterisation of phenolic compounds in wild fruits from Northeastern Portugal. Food Chem. 2013; 141: $3721-3730$. [CrossRef]

[16] Nenadis N, Llorens L, Koufogianni A, Diaz B, Font J, Gonzales JA, Verdaguer D. Interactive effects of UV radiation and reduced precipitation on the seasonal leaf phenolic content/composition and the antioxidant activity of naturally growing Arbutus unedo plants. J Photochem Photobiol B. 2015; 153: 435-444. [CrossRef]

[17] Küçükbay Z, Kuyumcu E. Determination of trace element contents of Thymus species from Turkey. Turk J Chem. 2010; 34: 911-919. [CrossRef]

[18] Huang DJ, Ou BX, Prior RL. The chemistry behind antioxidant capacity assays. J Agr Food Chem. 2005; 53: 1841-1856. [CrossRef]

[19] Büyüktuncel E. Main spectrophotometric methods for the determination of total phenolic content and antioxidant capacity. Marmara Pharm J. 2013; 17: 93-103. [CrossRef]

[20] Apak R, Güçlü K, Özyürek M, Karademir SE. Novel total antioxidant capacity index for dietary polyphenols and vitamins $\mathrm{C}$ and $\mathrm{E}$, using their cupric ion reducing capability in the presence of neocuproine: CUPRAC method. J Agr Food Chem. 2004; 52: 7970-7981. [CrossRef]

[21] Miller NJ, Rice Evans CA, Davies MJ, Gopiathan V, Milner A. A novel method for measuring antioxidant capacity and its application to monitoring the antioxidant status in premature neonates. Clinical Sci. 1993; 84: 407-412. [CrossRef]

[22] Benzie IF, Strain JJ. The ferric reducing ability of plasma (FRAP) as a measure of "antioxidant power": the FRAP assay. Anal Biochem. 1996; 239(1): 70-76. [CrossRef]

[23] Pellegrini N, Serafini M, Colombi B, Del Rio D, Salvatore S, Bianchi M, Brighenti F. Total antioxidant capacity of plant foods, beverages and oils consumed in Italy assessed by three different in vitro assays. J Nutr. 2003; 133(9): $2812-2819$. [CrossRef]

[24] Singleton VL, Joseph A, Rossi, JRJA. Colorimetry of total phenolics with phosphomolybdic-phosphotungstic acid reagents. Am J Enol Vitic. 1965; 16: 144-158.

[25] Slinkard K, Singleton VL. Total phenols analysis: automation and comparison with manual methods. Am J Enology Vitic. 1977; 28: 49-55. [CrossRef]

[26] Alkaya DB, Seyhan SA, Öztürk BN. Influence of extraction method on antioxidant properties of Rheum ribes root extract. Ovidius University Annals of Chemistry. 2019; 30(1): 44-47. [CrossRef]

[27] Perez-Jimenez J, Saura-Calixto F. Effect of solvent and certain food constituents on different antioxidant capacity assays. Food Res Int. 2006; 39(7): 791-800. [CrossRef]

[28] Finotti E, Majo D. Influence of solvents on the antioxidant property of flavonoids. Mol Nutr Food Res. 2003; 47(3): 186-187. [CrossRef]

[29] Dorman HJD, Peltoketo A, Hiltunen R, Tikkanen MJ. Characterisation of the antioxidant properties of de-odourised aqueous extracts from selected Lamiaceae herbs. Food Chem. 2003; 83(2): 255-262. [CrossRef] 
[30] Balkan İA, Taşkın T, Şah EA, Akaydın G, Yeşilada E. Comparative study of the anti-inflammatory, antioxidant and urease inhibitory activities of Eryngium kotschyi Boiss. and E. campestre L. var. virens (Link) Weins extracts. J Res Pharm. 2020; 24(3): 399-409. [CrossRef]

[31] Trouillas P, Calliste CA, Allais DP, Simon A, Marfak A, Delage C, Duroux JL. Antioxidant, anti-inflammatory and antiproliferative properties of sixteen water plant extracts used in the Limousin countryside as herbal teas. Food Chem. 2003; 80(3): 399-407. [CrossRef]

[32] Miliauskas G, Venskutonis PR, Van Beek TA. Screening of radical scavenging activity of some medicinal and aromatic plant extracts. Food Chem. 2004; 85: 231-237. [CrossRef]

[33] WHO, Quality control methods for medicinal plant materials, Geneva, Switzerland. 1998. [CrossRef]

[34] MacDonald-Wicks LK, Wood LG, Garg ML. Methodology for the determination of biological antioxidant capacity in vitro: A review. J Sci Food Agr. 2006; 86(13): 2046-2056. [CrossRef]

[35] Karasakal A. Evaluation of antioxidant activities of Brassica napus's seeds by CUPRAC, ABTS/Persulphate and DMPD methods. Marmara Pharm J. 2015; 19: 153-158. [CrossRef]

[36] Taskın T, Levent M, Şahin T. Investigation of the effects of biological activity and steeping time of four different black teas commercially valuable in Turkey. Clin Exp Health Sci. 2019; 9: 283-287. [CrossRef]

[37] Şavşatlı Y. The effects of wheatgrass length on antioxidant activity and total phenolic content in wheatgrass Triticum spp. Turk J Agric For. 2020; 44(3): 271-277. [CrossRef]

[38] Başkan KS, Tütem E, Özer N, Apak R. Spectrophotometric and chromatographic assessment of contributions of carotenoids and chlorophylls to the total antioxidant capacities of plant foods. J Agric Food Chem. 2013; 61(47): 11371-11381. [CrossRef]

[39] Yılmaz DÇ, Seyhan SA. Antioxidant potential of Cydonia oblonga Miller leaves. Istanbul J Pharm. 2017; 47(1): 9-11. [CrossRef]

[40] Mendes L, Freitas V, Baptista P, Carvalho M. Comparative antihemolytic and radical scavenging activities of strawberry tree (Arbutus unedo L.) leaf and fruit. Food Chem Toxicol. 2011; 49: 2285-2291. [CrossRef]

[41] Oliveiraa I,Baptistaa P, Malheiroa R, Casalb S, Bentoa A, Pereir JS. Comparative antihemolytic and radical scavenging activities of strawberry tree (Arbutus unedo L.) leaf and fruit. Food Res Int. 2011; 44: 1401-1407 [CrossRef]

[42] Çakmak H, Bozdoğan N, Turkut MG, Kumcuoğlu S, Tavman Ş. Evaluation of drying kinetics of Arbutus unedo L. fruit and determination of quality characteristics. Gida. 2016; 41(4): 227-234. [CrossRef]

[43] Moualek I, Aiche GI, Guechaoui NM, Lahcene S, Houali K. Antioxidant and anti-inflammatory activities of Arbutus unedo aqueous extract. Asian Pac J Trop Biomed. 2016; 6(11): 937-944. [CrossRef]

[44] Vidrih R, Hribar J, Prgomet Z, Ulrih NP. The physico-chemical properties of strawberry tree (Arbutus unedo L.) fruits. Croat J Food Sci Technol. 2013; 5(1): 29-33.

This is an open access article which is publicly available on our journal's website under Institutional Repository at http://dspace.marmara.edu.tr. 